Jurnal ASPIKOM, Vol. 6, No. 2, July 2021, pp. 303-314

P-ISSN: 2087-0442, E-ISSN: 2548-8309

DOI: http://dx.doi.org/10.24329/aspikom.v6i2.921

\title{
Exploring Self Identity: An Analysis of Audience Reception of Vlogs
}

\section{Menyelidiki Identitas Diri: Analisis Penerimaan Khalayak Terhadap Konten Vlog}

\author{
Rizki Briandana $^{1 *}$, Feni Fasta ${ }^{2}$, Eli Jamilah Mihardja ${ }^{3}$, Amer Qasem ${ }^{4}$ \\ ${ }^{1,2}$ Universitas Mercu Buana, Jl. Meruya Selatan No. 1, Jakarta Barat, Indonesia \\ ${ }^{3}$ Universitas Bakrie, Jl. HR Rasuna Said Kav C22, Jakarta Selatan, Indonesia \\ ${ }^{4}$ An-Najah National University, Omar Ibn Al-Khattab St., PO Box 7, Nablus, Palestine \\ *Corresponding author, e-mail: rizki.briandana@mercubuana.ac.id
}

\begin{abstract}
This study analyzed the interpretation of the self-identity projected by Tasya Farasha through her YouTube content. The development of youth identity today cannot be separated from the role of social media. In this context, Tasya Farasha's content was examined from the viewpoint of the audience who watched it. This study uses a reception analysis methodology with focus group discussion as data collection technique. The informants in this study were selected based on criteria and classified based on three different universities in Jakarta. The result showed that the informants perceived the content of Tasya Farasya's broadcast as a reference for youth in forming self-identity both culturally and persuasively in speech and action. The self-identity that Tasya Farasya projects led to a cosmopolitan identity. An identity that sees human's equality in a community. This self-identity also shows its resistance to various dogmas that discriminate against differences.
\end{abstract}

Keywords: Audience reception; Indonesian YouTuber; Vlogger; Self-identity

\begin{abstract}
Abstrak
Penelitian ini bertujuan untuk menganalisis interpretasi remaja terhadap identitas dirinya melalui konten YouTube Tasya Farasha. Perkembangan identitas remaja saat ini tidak lepas dari peran media sosial. Dalam konteks ini, konten Tasya Farasha dikaji dari sudut pandang khalayak yang menontonnya. Penelitian ini menggunakan metodologi analisis resepsi dengan focus group discussion sebagai teknik pengumpulan datanya. Informan dalam penelitian ini dipilih berdasarkan kriteria dan diklasifikasikan berdasarkan tiga Universitas berbeda di Jakarta. Hasil penelitian menunjukkan bahwa informan menginterpreatsi konten tayangan Tasya Farasya sebagai rujukan remaja dalam membentuk jati diri baik secara kultural maupun persuasif dalam tindakan. Identitas diri yang dipaparkan oleh Tasya Farasya mengarah pada identitas kosmopolitan. Identitas yang memandang kesetaraan manusia dalam suatu komunitas, identitas diri ini juga menunjukkan perlawanannya terhadap berbagai dogma yang mendiskriminasi perbedaan.
\end{abstract}

Kata Kunci: Analisis resepsi; Identitas diri; vlogger; Youtuber Indonesia 


\section{Introduction}

Millennial generation and social media are two things that cannot be separated from each other (Sajithra \& Patil, 2013). Millennial generation was born at a time when the most advanced era of internet technology was increasingly being used, especially in the use of social media as a communication and socializing platform (Pradsmadji \& Irwansyah, 2019). This generation is usually called the $\mathrm{Z}$ generation, and this generation was born between 1995 and 2012 (Turner, 2015). In this new media era, the internet offers easy communication to be no longer limited by space and time (Fauzi, Fasta, Nathan, \& Jeong, 2020). Social media as part of new media is something that always goes hand in hand with the millennial generation (Jamil, Rekarti, Briandana, \& Audinna, 2019). Social media, which has now become a medium for self-actualization, provides more and more benefits for its users (Scharrer \& Ramasubramanian, 2015). Not only in terms of entertainment and information, it also provides income for the users who use the content. 85 percent of Generation Z states that they use YouTube, 72 percent also uses Instagram and 69 percent uses Snapchat. YouTube itself has become a type of social media with the highest accessibility in Indonesia (Cunningham, Craig, \& Silver, 2016). Many types of contents have been uploaded on YouTube including food content, tourist attractions, beauty products, automotive products, variety shows, and dramas. Even some mass media have started uploading their content on YouTube, so that the audience can replay past shows that were aired on television (Jones, 2019). One of the highlights of the many contents uploaded on YouTube is the beauty product review content, also known as beauty vlogging (Feroz Khan \& Vong, 2014; Mulyana, Briandana, \& Fauziah, 2020). Make-up, which was previously used as a complement for women before traveling or attending certain events, has now become a hobby, entertainment, and even income for some people.

As one of the social media platforms, YouTube has a characteristic that its content is created by its users or better known as User Generated Content. This is supported by Holland (2016) in a study titled How YouTube Developed into a Successful Platform for User-Generated Content. Of the 3.2 billion people who have access to the internet, more than 1 billion people access the internet (Rahmi, Sekarasih, \& Sjabadhyni, 2016). Since people can upload and share videos online, YouTube has become part of the entertainment industry nowadays. User participation itself also creates audience stability. In the article, Holland (2016) concluded that YouTube has evolved from a content-sharing site to a platform for creating content by users or User Generated Content.

With technological developments, social media has been integrated into our lives and has provided new initiatives (Wardhani, Hesti, \& Dwityas, 2019). In recent years, social media has become an important advertising and communication platform for marketers who want to reach online consumers (Çiçek, 2018). According to Gümüş (2018), influencer marketing is defined as identifying Social Influencers and encouraging them to promote or endorse a brand or product on social media platforms. An influencer, a person who is defined as someone who has the potential to influence other people, does influencer marketing (Ioanid \& Scarlat, 2017). YouTube, Instagram, Pinterest, Blogs, Facebook, Snapchat, and Twitter are the media to which many influencers are referred (Hu, Manikonda, \& Kambhampati, 2014).

In the previous studies, it was revealed that product-related information on digital media affects the intensity of consumer purchases. Wang et al. (2012) stated that product reviews on social media such as Facebook have a greater influence on the 
intensity of consumer purchases than reviews made by advertising. This is because consumer reviews are interpreted as more informative and persuasive. Then, according to Fox et al. (2015), communication with peers on social media is related to a product or service that also affects the intensity of consumer's purchases by producing more positive consumer attitudes and involvement in the product.

In this context, the researchers analyze the audience's perspective in interpreting YouTube content. In the concept of reception analysis, the audience is seen as a part of interpretative communities who are always active in interpreting messages and producing meanings - not only being passive individuals who only accept messages produced by the mass media. The reception analysis emphasizes the use of media as a reflection of the socio-cultural context as a process of giving meaning.

From a conceptual aspect, Webster and Ksiazek (2012) and Marôpo (2014) argued that society uses media in various ways and for different needs. This refers to community interpretation activities where Brunsdon and Morley (2005) stated that the public could take advantage of the messages and meanings obtained through the content conveyed by the media to understand the activities of their daily life. In this case, people interpret based on their experiences.

The YouTube contents that were analyzed from the audience's perspective is created by YouTuber Tasya Farasha. Currently, Tasya Farasya's YouTube channel already has 3.14 million subscribers, and until March 14, 2020, it has 248,242,700 views. These numbers, of course, will increase as time goes by, aline with the activity of video uploading. Until 2020, Tasya Farasya has uploaded a total of 278 videos. The uploaded video is not only about make-up tutorial videos, but also videos of her visits to several facial care product factories, her collaboration videos with several brands, honest product reviews, sponsorship videos with some E-commerce, her wedding vlog video, and also question and answer videos. However, so far, in her YouTube video content, it has been more dominant in topics related to beauty. The information and learning provided by Tasya Farasya in her Vlog have made women, especially adolescents, increase their interest in learning about make-up and how to take care of themselves.

The researchers in this study have also conducted a pre-research before collecting data for this study. Referring to the pre-research data, it is known that subscribers have started to follow the YouTube of Tasya Farasaya from this interest. Through Tasya Farasya's YouTube, women can look up make-up inspiration, information about makeup tools, and facial care. Currently, beauty is not only about self-confidence, but also a person's identity. Not only beauty, appearance has also been considered as branding of oneself. What we display in front of others will shape one's self image in other people's perceptions (Chen \& Dermawan, 2020). The identity attached to a person can be seen from what is displayed, and how to be able to respect one's self is by forming a good self-identity. Therefore, many women are competing to meet beauty standards. Make-up becomes a tool to help give confidence (Berryman \& Kavka, 2017). How strong is the impact of make-up on women? A make-up is not only for self-confidence, but someone with good make-up and appearance will also be more appreciated (Mulyana et al., 2020).

Both on television and on social media, celebrities are identified as the main models that represent adolescents and have both positive and negative influences on adolescent attitudes through modeling without direct interaction (Mulyana, Briandana, \& Ningrum, 2019). Therefore, adolescents can be said to be in transitional periods 
searching for their identity and forming their identity (Briandana, Sofian, \& Azmawati, 2018). In addition, at times like this, adolescents need lots of references in shaping their identity and forming self-identity.

The adolescents who were studied in this study are those at the university level and live in West Jakarta, Central Jakarta, and South Jakarta. The location selection is based on Morley's (2003) concept that states that different social and economic backgrounds have different interpretations of media content.

Relevant previous studies are discussed as the main references in this study, namely: Youth, identity, and stigma in the media: From representation to the young audience's perception (Marôpo, 2014); New media audience and gender perspective: A reception analysis of millennials interpretation (Briandana \& Azmawati, 2021); Media Audiences| Digital Mediascapes, Institutional Frameworks, and Audience Practices Across Europe (Perusko, Vozab, \& Čuvalo, 2015); Transnational Audience Reception as a Theater of Struggle: Young Filipino Women's Reception of Korean Television Dramas (Espiritu, 2011).

These previous studies are the main references for the basis of this study. However, the researchers also criticized these studies, where the shift in viewing patterns via smartphones has a different dynamic from studies that focus on television. Regarding watching using smartphones, generation $\mathrm{Z}$ audiences who have different preferences and experiences from audiences born in the previous era usually dominate this activity. The existence of digital culture is an important point in the context of audience studies in the digital era. Therefore, this can be a contribution to research that focuses on digital content (Bonilla \& Rosa, 2015).

In this context, self-identity is also used as the main concept in this study. Forming self-identity is a long and complex process, which requires continuity from the past, present, and future (Schwartz \& Halegoua, 2015). The formation of self-identity does not occur in vacuum. Aspects of the social world play an essential role in the formation of a stable identity (Pan, Lu, Wang, \& Chau, 2017). This study looks at selfidentity from a different perspective, which is where the media plays an important role in the process. Self-identity is an awareness of oneself to explain who they are, so that a person feels as a unique and different person from others (Berzonsky, 2010; Escalas et al., 2013).

According to Bailey (2003), several stages need to be considered in forming selfidentity. Step I is an interweave of one's fixed human's nature and one's on-going acquired nature. Step II is selecting aspects out of Step I, interpreting one's experiences, and "feeling" one's interactions with people in building a system of values. A system of values consists of one's most cherished immaterial concepts of worth and most prized material aspirations of value. Both categories are extremely influential in determining one's decisions on life-shaping issues. Step III is prioritizing Step II values into a philosophy of life, with the archetype being its core value. Step IV is molding one's identity character traits out of one's philosophy of life. Step V, under the strong influence of monitored feedback from interactions with the outside world, is designing one's personality out of one's character. Step VI is producing work product from one's character and personality (Bailey, 2003).

The existence of idol figures seen by adolescents in television or on social media can make a significant contribution to the formation of self-identity (Berzonsky, 2010). Adolescents see, assess, and find interesting values from idol figures, then internalize them to become part of their formation of self-identity (Gauntlett, 2003). Television or 
social media celebrities have been identified as one of the main models representing many adolescents and were found to positively or negatively influence adolescent attitudes through modeling without direct interaction (Rashid, Rahman, \& Butt, 2017). Adolescents idolize and model famous figures without considering whether the character is good to be an idol figure. Based on this explanation, this study aims to analyze the interpretation of self-identity which is projected by Tasya Farasha through her YouTube content.

\section{Method}

This study used a reception analysis methodology with a constructivist paradigm. Reception analysis is an analysis that emphasizes the view of the audience and how they can produce meanings that are different from what is offered in the media text (Morley, 2003). This reception analysis focuses on seeing how different audiences interpret media content so that it takes a perspective on the audiences rather than the media itself (Tennyson \& Ray, 2005). This analysis also looks at the contextual influence on media use and the interpretation and meaning of all audience's experiences (Briandana, 2019). Therefore, the concept of reception analysis is important because this study wants to see how the audience perceives the meaning and pleasure of the media texts offered.

Reception analysis is one of the audience studies in the context of communication that examines acceptance and the meaning of the message by the public. The message received by the public through the media in everyday life, both as a topic of conversation and as a basis for activities carried out based on the topics being discussed. The audience has the freedom to interpret the meaning of the content of the messages conveyed by the media (Littlejohn \& Foss, 2010). Reception analysis is a concept that emphasizes the role of the audience in receiving messages, not on the role of the sender of the message (Briandana et al., 2018). This analysis tries to understand how the audience interprets the messages conveyed by the media so that these audiences accept and follow the messages they get. According to McQuail (2015), reception analysis emphasizes the use of media as a reflection of the socio-cultural context and as a process of giving meaning through audience's perceptions of experience and production.

This study is based on the viewpoint of cultural studies using Stuart Hall's encoding-decoding theory. Based on Hall's framework, the coded message is interpreted by the audience (Hall, 2003). Three categorizations for audience coding, namely dominant, negotiated, and oppositional readings (Hall, 2003). Dominant or preferred readings are produced when an audience completely violates the ideology of the government that the class interprets television according to the purpose of selecting the meaning encoded on the text by the television publisher or writer. Negotiated readings are generated when the audience makes meaningful, personal interpretations with different content. Oppositional readings are produced when the audience interprets a message that directly conflicts with the message code (Shaw, 2017).

The data collection technique in this study used focus group discussion. The selection of informants in this study refers to the following criteria: 1) the informants fall into the upper adolescent category with an age range of 21-24 years; 2) the informants have watched Tasya Farasha's YouTube; 3) the informants come from different backgrounds, i.e. living in the Jakarta area and from different universities.Based on these criteria, eight informants were selected in this study. These informants came from three Universities across Jakarta; Universitas Mercu Buana, 
Universitas Bakrie, and Universitas Muhammadiyah Jakarta.

\section{Results and Discussion}

To obtain the results of the study, the researchers collected data by conducting a focus group discussion; the discussion took place by forming two groups, with each group having four speakers. The informants were selected based on the category of adolescents (female and male) aged 21-24 years. They are students, followers of Tasya Farasya's Instagram social media, and also Tasya Farasya's YouTube subscribers. The discussion was carried out in-depth regarding the resource's knowledge of Tasya's Youtube content.

In the process of forming self-identity, many references are needed to look for things that we like and dislike, what is suitable for ourselves, what is not suitable, and what kind of process we want others to see. Self-identity is not only formed by itself. Many things affect the process of forming self-identity. Over time, internet technology began to develop rapidly, and adolescents had no trouble finding references for various things on the internet. Social media is starting to become a place for all of us to share a lot of content. YouTube, in particular, has also become the main place for creators to upload various kinds of educational content. Tasya Farasya uses her YouTube to convey messages to her followers regarding various educational content about beauty procedures and tips-and-tricks. The contents consist of tips in choosing facial skincare, make-up products, make-up tutorials, and reviews of every beauty product. The content of beauty vlogger shows can also be used as a reference for females and males in their process of forming their own identity as they want, and make-up is used as a tool to express themselves in their environment. Therefore, what someone displays forms their identity in public. The following are the informants' reasons for choosing Tasya Farasya as a reference in forming self-identity.

I live my life following Tasya's concept of life. Tasya once said that life doesn't need to be complicated. Whatever the circumstances, just keep going. Sometimes we need privacy, but don't close ourselves off. From those words, I have shaped myself to become a person with an identity of being a brave, relaxed, confident and independent woman. (Informant 1, August 2020)

I like make-up and my identity is known by the eyes makeup I use. People identify me as "oh the Arab who wears sipat mata (eye liner)'. (Informant 2, August 2020)

I like my character style, which other people do not necessarily feel comfortable wearing. I came to know what suits me and what I want to display comfortably. (Informant 3, August 2020)

Meanwhile, there were different opinions from informants in group II's discussion. According to them, Tasya Farasya's broadcast content also plays a role in the process of forming self-identity through motivation. According to an informant's view, one of Tasya Farasya's uploads influences is when Tasya always reminds others to not feel insecure and to always be confident. In fact, that is what made the informant to be brave enough to upload her passion for make-up by sharing make-up tutorials, or photos of her make-up results on Instagram.

On the other hand, an informant said that Tasya Farasya's identity influenced them in her makeup style. All the information that Tasya Farasya conveyed about the 
product and the tutorial succeeded in making the informant continue to form his identity. Previously, the informant was very insecure and could not even use an eyebrow pencil. Several informants said that the tutorial from Tasya and its motivational content made the informants changed their appearance and were identical in using an eyebrow pencil.

The same opinion also came from three informants. They argued that Tasya Farasya makes them more confident in creating an appearance. She makes them aware of their strengths and weaknesses and what fits and does not fit them. In fact, according to the three of them, the content of Tasya Farasya's YouTube makes them know themselves more deeply and have more self-respect to continue to take good care of themselves. According to them, the role of Tasya's broadcast content in forming selfidentity lies more in the desire to explore themselves further and have the courage to convey and present what is fun and what they are happy to show.

Tasya's content makes me more creative and confident in my abilities and makes me want to express myself. I want to present myself for make-up by uploading my make-up content on Youtube and Instagram with the identity of my make-up that features quirky eyeshadow, overline lipstick and western-style freckles. In fact, I want to tell my favorite stuff and my identity to the public. My friends even labeled me as a "beauty enthusiast". (Informant 4, August 2020)

From the way Tasya explains something, it is straightforward, clear, and detailed. So, I want to copy her technique in public speaking. So that I can speak the right language every time I speak in public, so that the audience can equally understands easily. (Informant 5, August 2020)

The informants are active users of social media. The results of the research that the researchers obtained came from various informants with different backgrounds. A YouTuber can be defined as someone who is known as a YouTube content creator (Pradsmadji \& Irwansyah, 2019). YouTubers emerged because YouTube social media's function is to host content in the form of videos. Not only uploading videos, we can also enjoy videos for free only with an internet network (Prestianta, Nusantara, \& Serpong, 2021). YouTube can also be used as a productive field for content creators. Therefore, various groups are competing to produce works on YouTube. These contents start from beauty content, gamers, motivation, cooking tutorials, comedy, and various kinds of useful content to generate loyal viewers and subscribers who generate income for YouTubers.

Currently, YouTube is widely watched by various groups, both young and old (Holland, 2016). YouTube has a wider reach than television (Astuti, Giri, \& Hidayah, 2020). This can be proven from the habits of Indonesian people in searching for video content (Ananda \& Wandebori, 2016). This is also why informants become YouTube users to look for references in developing and forming self-identities (Fiani \& Sarwono, 2017). The informants subscribe to the creator's content that they think they should follow and impact them. Thus, these creators are not only being followed but also being used as a role model in the process of forming one's own identity.

This is consistent with the instincts of adolescents who want to find out more and look for various references for them to follow and their examples (Jones, 2019). Being a role model for adolescents is very important to help them form their identity as they want. They can also be a model for what kind of people these adolescents want to be known, what they want to be seen, and what freedom of expression they want to show 
(Yang, Lin, Carlson, \& Ross Jr, 2016). This is especially true in this day and age where the trend of makeup and various local cosmetics have spread its wings in the Indonesian industry. Adolescents also flock to start forming their own identities by expressing themselves through make-up. Not only make-up, various skin treatments are also a mainstay for teenage beauty activists to maximize their make-up by having healthy skin. With so many viewers turning to online video, it is only natural that many brands have also changed their medium to stay relevant and be heard of. One of them is by choosing YouTube as their brand communication campaign channel (Cunningham et al., 2016). It is because at this time, people - especially adolescents - access social media more than television. They spend more time surfing on social media than watching television, which they think is monotonous. In addition, YouTube has become a medium in determining decisions, especially when looking for references in forming self-identity (Moor, Heuvelman, \& Verleur, 2010).

Based on the data results, it can be concluded that in interpreting social media, the public has its own power in terms of interpretation. This is very influential on the sociocultural background of the sources where they have a culture or habits and even their own tastes that have been formed according to their respective environments.

The meaning raised by the audience results from the phenomenon of forming selfidentity, which is a cultural and social belief that is the choice of the audience to look for references in the formation of self-identity. The audiences shape their identities through the influence of the media. Media provide an effect or stimulation for the audiences to form their own identities according to the constructs of social media.

The lifestyle that is formed among adolescents is a lifestyle of recognition of their respective identities. The informants absorbed this because they enjoyed and accepted that a person's appearance, beauty, and self-confidence, especially a woman, are very necessary.

Therefore, the informants indirectly form self-identity according to the content they watch in the media. Tasya Farasya's content is now a reference for informants in the formation of self-identity. The reception of this message has a positive value for the people who watched the content of Tasya Farasya's broadcast. Referring to the data results, the self-identity projected by Tasya Farasya in her contents leads to a cosmopolitan identity. Cosmopolitanism, in its development, believes that humans are in the same community where the main identity of that society is as a human being himself (Delanty, 2012; Skovgaard-Smith \& Poulfelt, 2018). In this context, the YouTube content that is watched by the audience plays a role in shaping the identity of the audience. Tasya Farasya in her content, describes all forms of values that lead to cosmopolitanism.

Based on the explanation above, it can be seen that the majority of the audience is in the dominant party. It means that they believe Tasya Farasa's broadcast content can provide informative things for the viewers. In this context, dominant refers to the Stuart Hall's concept which is produced when the audience violates the ideology of the government and interprets the media according to the purpose of selecting the meaning encoded in the text (Shaw, 2017).

In fact, following Tasya Farasya on YouTube and Instagram can help the audiences get references to find their own identity. The audiences also get motivation, innovation, tips and tricks, culture and communication knowledge. If we look at the audiences' interest in Tasya Farasya's content, they stated that Tasya Farasya's content is interesting, very clear in its delivery, useful, and motivating. 
Another meaning seen from the acceptance of adolescents in the formation of selfidentity through Tasya Farasya's YouTube is that the majority of the audience stated that Tasya Farasya's content had an influence on them in society. Therefore, they can easily view and imitate the content that Tasya Farasya shares.

Furthermore, the informants who watch Tasya Farasha's YouTube are actively viewing the selected program content "consciously". They will take the time to direct their attention to the program that is being watched. This is in contrast to the type of "television audience" who often performs random viewings based solely on their interest in programs that happen to catch their attention at a particular moment.

The results of this analysis can then answer differently to the results of research proposed by Gray (1999) and Gillespie (2005), which stated that the direction of the audience has moved towards "content as a product category"-where the audience is more interested in television as a media without having a specific interest in the channel or program being broadcasted. On the contrary, in this study, it was shown by the informants that they, as the audience, use YouTube to select specific programs and channels as a brand that is deemed appropriate to their interests and needs.

\section{Conclusion}

In this study, it is concluded that when the audiences were watching a program, they identify themselves with a character who is considered to reflect positive values as a reference in building self-identity. The depiction of figures in the content being watched provides a kind of reference for the audiences to shape their identities. The audiences are looking for references for them in order to know what is suitable and comfortable for them to use and display. In the process of forming self-identity, a role model is needed to support someone in creating an appearance and being more able to express themselves, such as what other people want to form. Therefore, adolescents are looking to shape their own characteristics so that others know them as they expect it.

In accordance with the research objectives, there were various results regarding the interpretation of Tasya Farasya's YouTube content. Most of the informants perceived the content of Tasya Farasya's broadcast as a reference for youth in forming self-identity both culturally and persuasively in speech and in action. The self-identity that is projected by Tasya Farasya leads to a cosmopolitan identity. As an identity that sees human's equality in a community, this self-identity also shows its resistance to various dogmas that discriminate against differences. In this case, the content created by Tasya Farasya promotes a celebration of difference and imperfection, something postcolonialism has always rejected. It is hoped that further studies can analyze a more diverse audience. This is because the audiences are always moving in line with the dynamics of culture and technology that always develop. In addition, social media is used as the main preference for today's audiences.

\section{Acknowledgements}

The authors would like to thank Universitas Mercu Buana for the funding of the research. We also would like to thank Universitas Bakrie for the collaborative research and the alumni of School of Communication, USM, for their support in finishing this research. 


\section{References}

Ananda, A. F., \& Wandebori, H. (2016). The impact of drugstore makeup product reviews by beauty vlogger on YouTube towards purchase intention by undergraduate students in Indonesia. In International Conference on Ethics of Business, Economics, and Social Science (Vol. 3, pp. 264-272).

Astuti, S. I., Giri, L., \& Hidayah, N. (2020). VIDEO WEB DRAMA SERIES FOR COMBATING DISINFORMATION. Aspiration Journal, 1(1), 1-30.

Bailey, J. A. (2003). Self-image, self-concept, and self-identity revisited. Journal of the National Medical Association, 95(5), 383.

Berryman, R., \& Kavka, M. (2017). 'I guess a lot of people see me as a big sister or a friend': The role of intimacy in the celebrification of beauty vloggers. Journal of Gender Studies, 26(3), 307-320.

Berzonsky, M. D. (2010). Cognitive processes and identity formation: the mediating role of identity processing style. Psychologia Rozwojowa, 15(4), 13-27.

Bonilla, Y., \& Rosa, J. (2015). \# Ferguson: Digital protest, hashtag ethnography, and the racial politics of social media in the United States. American Ethnologist, 42(1), 4-17.

Briandana, R. (2019). Television and National Identity: An Ethnography of Television Audience in the Border of Indonesia-Malaysia. Jurnal Ilmu Sosial Dan Ilmu Politik, 23(1), 72-85. https://doi.org/10.22146/ jsp.27205

Briandana, R., \& Azmawati, A. A. (2021). The influx of national identity: "imagined communities" on Indonesian audience in Indonesia and Malaysia frontier. Jurnal Studi Komunikasi (Indonesian Journal of Communications Studies), 5(1), 24. https://doi.org/10.25139/jsk.v5i1.2846

Briandana, R., Sofian, M. R., \& Azmawati, A. A. (2018). Pay Tvs and Audience Reception: Intercultural Responses to K-Drama on Indonesian Audience. International Journal of Communication Research, 8(4), 285.

Brunsdon, C., \& Morley, D. (2005). The Nationwide Television Studies. London and New York: Routledge.

Chen, J.-L., \& Dermawan, A. (2020). The Influence of YouTube Beauty Vloggers on Indonesian Consumers' Purchase Intention of Local Cosmetic Products. International Journal of Business and Management, 15(5), 100-116.

Çiçek, B. (2018). Social Media Entrepreneurship. İçtimaiyat, 2(1), 10-17.

Cunningham, S., Craig, D., \& Silver, J. (2016). YouTube, multichannel networks and the accelerated evolution of the new screen ecology. Convergence, 22(4), 376391.

Delanty, G. (2012). Handbook of Cosmopolitanism Studies. Routledge.

Escalas, J., White, K., Argo, J. J., Sengupta, J., Townsend, C., Sood, S., ... Berger, J. (2013). Self-identity and consumer behavior. Journal of Consumer Research, 39(5), xv-xviii.

Espiritu, B. F. (2011). Transnational Audience Reception as a Theater of Struggle: Young Filipino Women's Reception of Korean Television Dramas. Asian Journal of Communication, 21(4), 355-372.

Fauzi, E. P., Fasta, F., Nathan, R. J., \& Jeong, S. W. (2020). Modern Muslimah in Media: a Study of Reception Analysis in "Saliha" Program on Net Tv. Aspiration, $1(2), 135-162$.

Feroz Khan, G., \& Vong, S. (2014). Virality over YouTube: an empirical analysis. Internet Research, 24(5), 629-647. 
Fiani, I. D., \& Sarwono, B. K. (2017). User-Generated Content and The Artificial Consumption Needs Through System Of Sign: Semiotics Study on Beauty Vlogger Video on YouTube. In Indonesia International Graduate Conference on Communication (IndoIGCC) Proceeding (Vol. 1, pp. 416-425).

Fox, J., Cruz, C., \& Lee, J. Y. (2015). Perpetuating online sexism offline: Anonymity, interactivity, and the effects of sexist hashtags on social media. Computers in Human Behavior, 52, 436-442.

Gauntlett, D. (2003). Media, gender and identity: An introduction. London \& New York: Routledge.

Gillespie, M. (2005). Media Audiences (Vol. 2). United Kingdom: Open Univ Pr.

Gray, A. (1999). Audience and Reception Research in Retrospect: The Trouble with Audiences. Rethinking the Media Audience: The New Agenda, 22-37.

Gümüş, N. (2018). Consumers' Perceptions of YouTubers: The Case of Turkey. Online Academic Journal of Information Technology, 9. https://doi.org/10.5824/1309

Hall, S. (2003). Encoding/decoding. Television: Critical Concepts in Media and Cultural Studies, 4(1), 43-53.

Holland, M. (2016). How YouTube Developed into a Successful Platform for UserGenerated Content. Elon Journal of Undergraduate Research in Communications, 7, 1. https://doi.org/http://www.inquiriesjournal.com/a?id=1477

Hu, Y., Manikonda, L., \& Kambhampati, S. (2014). What we instagram: A first analysis of instagram photo content and user types. In Eighth International AAAI conference on weblogs and social media.

Ioanid, A., \& Scarlat, C. (2017). Factors influencing social networks use for business: Twitter and YouTube analysis. Procedia Engineering, 181(3), 977-983.

Jamil, A., Rekarti, E., Briandana, R., \& Audinna, S. (2019). The Role of Social Media Hashtags in Political Promotions: Mediating Role of Supply Chain Communication. International Journal of Supply Chain Management, 8(6), 181188. https://doi.org/https://doi.org/10.4324/97813157750

Jones, L. (2019). Discourses of transnormativity in vloggers' identity construction. International Journal of the Sociology of Language, 2019(256), 85-101.

Littlejohn, S. W., \& Foss, K. A. (2010). Theories of human communication. Waveland press.

Marôpo, L. (2014). Youth, identity and stigma in the media: From representation to the young audience's perception. Journal of Audience and Reception Studies, 11(1), 199-212.

McQuail, D. (2015). Mass communication. The International Encyclopedia of Political Communication, 1-12.

Moor, P. J., Heuvelman, A., \& Verleur, R. (2010). Flaming on YouTube. Computers in Human Behavior, 26(6), 1536-1546.

Morley, D. (2003). Television, audiences and cultural studies. London and New York: Routledge.

Mulyana, A., Briandana, R., \& Fauziah, E. (2020). Indonesian Beauty Vlogger: YouTube as Social Engineering Tools for $\mathrm{Z}$ Generations. In International Conference on Social and Political Science B-Space (pp. 108-114). Malang: EAI. https://doi.org/10.4108/eai.26-11-2019.2295172

Mulyana, A., Briandana, R., \& Ningrum, D. A. P. (2019). Social Construction Fandom as Cultural Industry Marketing of JKT 48 Fan Group. International Research Journal of Business $\quad$ Studies, 12(3), 257-266. 
https://doi.org/https://doi.org/10.21632/irjbs.12.3.257-266

Pan, Z., Lu, Y., Wang, B., \& Chau, P. Y. K. (2017). Who do you think you are? Common and differential effects of social self-identity on social media usage. Journal of Management Information Systems, 34(1), 71-101.

Perusko, Z., Vozab, D., \& Čuvalo, A. (2015). Media Audiences| Digital Mediascapes, Institutional Frameworks, and Audience Practices Across Europe. International Journal of Communication, 9(4), 23.

Pradsmadji, S. I., \& Irwansyah, I. (2019). Media Convergence in the Platform of Videoon-Demand: Opportunities, Challenges, and Audience Behaviour. Jurnal ASPIKOM, 11(2), 141. https://doi.org/10.24912/jk.v11i2.4060

Prestianta, A. M., Nusantara, M., \& Serpong, G. (2021). Mapping the ASEAN YouTube Uploaders Pemetaan Pengunggah Video YouTube dari Negara ASEAN. Jurnal ASPIKOM, 6(1), 1-12.

Rahmi, Y., Sekarasih, L., \& Sjabadhyni, B. (2016). The influence of beauty vlog on perceived source credibility and purchase intention. Makara Hubs-Asia, 20(2), $13-23$.

Rashid, K., Rahman, B. H., \& Butt, A. R. (2017). Media Consumption and National Identity Formation of Adolescents in Pakistan. Journal of Media Studies, 32(1), 1-31. https://doi.org/10.1006/jado.1998.0201

Sajithra, K., \& Patil, R. (2013). Social media--history and components. Journal of Business and Management, 7(1), 69-74.

Scharrer, E., \& Ramasubramanian, S. (2015). Intervening in The Media's Influence on Stereotypes of Race and Ethnicity: The Role of Media Literacy Education. Journal of Social Issues, 71(1), 171-185.

Schwartz, R., \& Halegoua, G. R. (2015). The spatial self: Location-based identity performance on social media. New Media \& Society, 17(10), 1643-1660.

Shaw, A. (2017). Encoding and decoding affordances: Stuart Hall and interactive media technologies. Media, Culture \& Society, 39(4), 592-602.

Skovgaard-Smith, I., \& Poulfelt, F. (2018). Imagining 'non-nationality': Cosmopolitanism as a source of identity and belonging. Human Relations, 71(2), 129-154.

Tennyson, P. A., \& Ray, K. (2005). Reaching Today's Utility Audiences: Why There Is No Such Thing as the General Public. American Water Works Association. Journal, 97(1), 49.

Turner, A. (2015). Generation Z: Technology and social interest. The Journal of Individual Psychology, 71(2), 103-113.

Wang, X., Yu, C., \& Wei, Y. (2012). Social media peer communication and impacts on purchase intentions: A consumer socialization framework. Journal of Interactive Marketing, 26(4), 198-208.

Wardhani, D., Hesti, S., \& Dwityas, N. A. (2019). Uses and Gratifications of Social Media: Media Use Among University Students in Jakarta. International Journal of Communication Reserach, 9(1), 23-31.

Webster, J. G., \& Ksiazek, T. B. (2012). The Dynamics of Audience Fragmentation: Public Attention in an Age of Digital Media. Journal of Communication, 62(1), 39-56.

Yang, S., Lin, S., Carlson, J. R., \& Ross Jr, W. T. (2016). Brand engagement on social media: will firms' social media efforts influence search engine advertising effectiveness? Journal of Marketing Management, 32(5-6), 526-557. 